\title{
KEROKHANIAN SAPTA DARMA DAN PERMASALAHAN HAK- HAK SIPIL PENGHAYAT DI INDONESIA
}

\section{KEROKHANIAN SAPTA DARMA AND THE PROBLEM OF CIVIL RIGHTS OF ITS FOLOWERS IN INDONESIA}

\author{
Hanung Sito Rohmawati \\ IAIN Syekh Nurjati Cirebon
}

hanung.sito@gmail.com

\begin{abstract}
ABSTRAK: Kerokhanian Sapta Darma merupakan salah satu aliran kepercayaan terhadap Tuhan Yang Maha Esa. Berdasarkan Penetapan Presiden RI Nomor 1/PNPS Tahun 1965 Aliran kepercayaan berbeda dengan agama. Adanya pembedaan ini berimplikasi pada perbedaan kebijakan Negara untuk penganut agama dan penghayat kepercayaan sehingga menimbulkan permasalahan hak-hak sipil penghayat kepercayaan di Indonesia. Penelitian ini merupakan penelitian kualitatif, penulis menggunakan metode wawancara dan observasi untuk pengumpulan data penelitian. Fokus penelitian ini yaitu penghayat Kerokhanian Sapta Darma di Sanggar Candi Sapta Rengga. Dari penelitian ini penulis menemukan bahwa terdapat beberapa permasalahan hak-hak sipil penghayat Kerokhanian Sapta Darma, terutama sebelum adanya UU No. 23/2006. Permasalah hak-hak sipil antara lain hak atas pencantuman identitas di kolom agama dalam KTP; hak atas pencatatan dan registrasi perkawinan antar penghayat di Kantor Catatan Sipil; hak atas pendidikan, dalam hal ini hak anakanak penghayat untuk mendapatkan pendidikan agama sesuai dengan kepercayaannya; hak atas sumpah jabatan sesuai dengan kepercayaannya bagi PNS; hak atas lahan pemakaman dan penguburan sesuai dengan kepercayannya; hak untuk berkumpul dan membangun rumah ibadah.

Kata Kunci: Kerokhanian Sapta Darma' ${ }^{1}$, Hak-hak Sipil2, Aliran Kepercayaan ${ }^{3}$.
\end{abstract}

ABSTRACT: Kerokhanian Sapta Darma is one of the creeds religion in God Almighty. Based on the Determination of the President of the Republic of Indonesia Number 1/PNPS in 1965 that the followers of creeds religion are different from religion. The existence of this distinction has implications for differences in state policies for religious adherents and the followers of the faith which raises the problem of the civil rights of the followers of the faith in Indonesia. This research is a qualitative research that the writer uses interview and observation methods to collect research data. The focus of this research is the advocate of Kerokhanian Sapta Darma in the Sapta Rengga Temple Studio. From this study the authors found that there were several civil rights issues for Kerokhanian Sapta Darma advocates, especially before Law No. 23/2006. Issues of civil rights include the right to the inclusion of identity in the column of religion in the KTP; the right to record and registration of marriages between residents at the Civil Registry Office; the right to education, in this case the right of the children of the descendants to obtain religious education in accordance with their beliefs; the right of the oath of office in accordance with his belief in civil servants; the right of burial grounds and burial in accordance with their trust; the right to gather and build houses of worship.

Keyword: Kerokhanian Sapta Darma ${ }^{1}$, Civil Rights², Creeds Religion ${ }^{3}$

\section{A. PENDAHULUAN}

Kerokhanian Sapta Darma merupakan salah satu Kepercayaan terhadap Tuhan Yang Maha Esa yang ada di Indonesia. Dalam pandangan masyarakat luas Kepercayaan terhadap Tuhan Yang Maha Esa bukanlah suatu agama. Hal ini didukung oleh pembatasan definisi agama yang diberikan oleh Departemen Agama tahun 1962 bahwa 
agama mempunyai unsur-unsur penting antara lain mempunyai nabi, kitab suci, dan ada pengakuan internasional. ${ }^{1}$ Dengan demikian Kepercayaan terhadap Tuhan Yang Maha Esa belum dapat disebut sebagai agama. Adanya pembedaan antara agama dan Kepercayaan terhadap Tuhan Yang Maha Esa menimbulkan ketegangan di tengah masyarakat Indonesia.

Ketegangan antara penganut agama dan penghayat Kepercayaan terhadap Tuhan Yang Maha Esa didukung adanya peraturan-peraturan negara yang mengikat keduanya. Salah satunya yaitu dengan dikeluarkannya UU No.1/PNPS/1965 tentang Pencegahan dan Penyalahgunaan dan Penodaan Agama Pasal 1 menyebutkan: "Setiap orang dilarang dengan sengaja di muka umum menceritakan, menganjurkan, atau mengusahakan dukungan umum, untuk melakukan penafsiran tentang suatu agama yang dianut di Indonesia atau melakukan kegiatan-kegiatan keagamaan dari agama itu; penafsiran dan kegiatan mana menyimpang dari pokok-pokok ajaran agama”. Penetapan Presiden Inilah yang dalam perkembangannya digunakan sebagai alat untuk membentengi agama-agama yang diakui negara dari "serangan" aliran-aliran sempalan".

Menurut Musdah Mulia Undang-Undang tersebut cukup netral karena sekedar mengingatkan warga negara untuk bersikap hati-hati melemparkan tuduhan yang menodai komunitas agama, aturan itu juga berlaku umum bagi penganut agama dan penghayat kepercayaan terhadap Tuhan Yang Maha Esa. Akan tetapi, peraturan tersebut digunakan Pemerintah sebagai legitimasi untuk "mengamankan" agama-agama yang diakui negara (Islam, Protestan, Katolik, Hindu dan Buddha) terhadap tindakan penyimpangan dan penistaan dari kelompok-kelompok agama atau kepercayaan lain. Hal ini menguntungkan agama-agama yang diakui negara untuk mengontrol tumbuhnya kelompok-kelompok agama di luar agama yang diakui negara dan kelompok kepercayaan yang mungkin dapat mengganggu kekuasaan negara saat itu. ${ }^{3}$

Dikeluarkannya UU No.1/PNPS/1965, berimbas pada penafian hak-hak sipil yang keyakinannya berada di luar "agama yang diakui negara". Kebijakan tersebut diperkuat pada tahun 1978 MPR Menetapkan TAP MPR No. IV/MPR/1978 tentang GBHN. Dalam

\footnotetext{
${ }^{1}$ Hasbullah Bakry “ Bicara Tentang Definisi Agama” dalam H.M As'ad El Hafidy, Aliran-aliran Kepercayaan dan Kebatinan di Indonesia (Jakarta: Ghalia Indonesia, 1982), hlm. 123.

2 Tedi Kholiludin, Kuasa Negara Atas Agama Politik Pengakuan, Diskursus "Agama Resmi" dan Diskriminasi Hak Sipil (Semarang: RaSalL Media Group, 2009), hlm. 159.

${ }^{3}$ Siti Musdah Mulia, "Potret Kebebasan Beragama dan Berkeyakinan di Era Reformasi" dalam Elza Peldi Taher, ed., Merayakan Kebebasan Beragama Bunga Rampai 70 Tahun Djohan Effendi (Jakarta: ICRP kerjasama dengan Penerbit Buku Kompas, 2009), hlm. 337-339.
} 
ketetapan tersebut ditegaskan bahwa "Kepercayaan terhadap Tuhan Yang Maha Esa bukan merupakan agama”. Berangkat dari ketetapan ini, Menteri Agama mengeluarkan Instruksi No 4 dan 14 tahun 1978 yang menggariskan kebijakan inti mengenai aliran kepercayaan, dan melayangkan surat kepada para Gubernur dan Bupati/Walikota menyangkut berbagai aspek aliran kepercayaan.

Intervensi negara terhadap agama dan Kepercayaan terhadap Tuhan Yang Maha Esa juga muncul dalam Surat Edaran Mentri Dalam Negeri No. 477/74054/1978 yang menyebutkan: Agama yang diakui pemerintah, yaitu Islam, Katolik, Kristen/Protestan, Hindu dan Buddha. Sehingga agama dan Kepercayaan terhadap Tuhan Yang Maha Esa di luar lima agama itu menjadi kelompok yang termarjinalkan. Dampak dari adanya pendefinisian "agama yang diakui”" komunitas Kepercayaan terhadap Tuhan Yang Maha Esa menjadi target kolonisasi agama yang diakui negara melalui islamisasi atau kristenisasi. $^{4}$

Kedudukan yang tidak setara antara agama dan Kepercayaan terhadap Tuhan Yang Maha Esa di Indonesia menimbulkan perbedaan kebijakan, jika agama-agama yang diakui itu diatur di bawah Kementrian Agama sedangkan komunitas kepercayaan terhadap Tuhan Yang Maha Esa diatur di bawah pengawasan Dinas Pendidikan dan Kebudayaan. Atas pembedaan antara agama dan kepercayaan menimbulkan masalahmasalah hak-hak sipil yang dialami oleh kepercayaan terhadap Tuhan YME. Permasalahan sosial antara lain: masalah penyebaran dakwah, perkawinan, kematian, dan tanah makam ${ }^{5}$.

Penelitian ini memfokuskan kepada enam hak-hak sipil yang masih bermasalah dalam pemenuhannya kepada kelompok penghayat kepercayaan Kerokhanian Sapta Darma. Keenam hak-hak tersebut antara lain hak atas pencantuman identitas di kolom agama dalam KTP; hak atas pencatatan dan registrasi perkawinan antar penghayat di Kantor Catatan Sipil; hak atas pendidikan, dalam hal ini hak anak-anak penghayat untuk mendapatkan pendidikan agama sesuai dengan kepercayaannya; hak atas sumpah jabatan sesuai dengan kepercayaannya bagi PNS; hak atas lahan pemakaman dan penguburan sesuai dengan kepercayannya; hak untuk berkumpul dan membangun rumah ibadah.

\footnotetext{
${ }^{4}$ Ibid, hlm. 338-340.

5 Iman Supardi DS, "Konflik Antara Golongan Kerohanian Sapta Darma Dengan Golongan Santri Di Gresik 1978-1983", Universitas Jember, Makalah diseminarkan pada seminar akademik mahasiswa Sejaeah Universitas Negeri se-Jawa, Yogyakarta 9-10 Nov 1985.
} 


\section{B. METODE PENELITIAN}

Penelitian ini merupakan penelitian kualitatif, fokus pada penelitian ini yaitu penghayat Kerokhanian Sapta Darma di Sanggar Candi Sapta Rengga Yogyakarta. Sumber data dalam penelitian ini berasal dari dua sumber. Pertama, sumber lapangan yaitu tokoh dan masyarakat penghayat Kerokhanian Sapta Darma di Sanggar Candi Sapta Rengga Yogyakarta. Kedua, Sumber data dokumenter, yang terdiri atas sumber data dokumenter primer dan sumber data dokumenter sekunder. Metode pengumpulan data yang digunakan dalam penelitian ini yaitu wawancara dan dokumentasi. Sedangkan analisis yang dipakai dalam penelitian ini yaitu analisis data model interaktif menurut Miles dan Huberman yang terdiri dari empat tahapan yaitu tahap pengumpulan data, reduksi data, display data, dan penarikan kesimpulan atau verifikasi.

\section{HASIL DAN PEMBAHASAN}

\section{Sejarah dan ajaran Kerokhanian Sapta Darma}

Sapta Darma merupakan ajaran berdasarkan wahyu yang diterima oleh Bapak Hardjosopoero yang mempunyai nama kecil Sopoero, yang kemudian juga dikenal dengan nama Sri Gutama. Sri Gutama merupakan gelar yang diberikan kepada Bapak Hardjosopoero sebagai Panuntun Agung Sapta Darma yang dianugerahkan oleh Hyang Maha Kuasa pada tanggal 27 Desember 1955. Tiga tahun setelah beliau mendapat wahyu sujud pada tanggal 27 Desember 1952 di Pare, Kediri ${ }^{6}$.

Bapak Hardjosopoero merupakan anak pertama dari pasangan suami istri Bapak Soehardjo dan Soelijah yang lahir di desa Pare, Kediri pada tanggal 27 Desember 1914. Beliau menamatkan Sekolah Dasar pada tahun 1925. Beliau bekerja sebagai tukang pangkas rambut dan sebagai pedagang kecil, jual beli mas dan sebagainya. Beliau aktif mengikuti kegiatan Perkumpulan dan Perjuangan Rakyat pada masa penjajahan Belanda. Dan pada tahun 1937 aktif mengikuti kegiatan organisasi Kepanduan Surya Wirawan dan juga menjadi anggota PARINDRA (Partai Indonesia Raya) yang dipimpin oleh Saudara Kasran di Pare, Kediri?

Penghayat Kerokhanian Sapta Darma meyakini bahwa Sapta Darma merupakan ajaran yang berasal dari wahyu bukan wangsit semata, karena wangsit hanya terbatas bagi

\footnotetext{
${ }^{6}$ Sekertariat Tuntunan Agung Kerokhanian Sapta Darma, Sejarah Penerimaan Wahyu Wewarah Sapta Darma dan Perjalanan Panuntun Agung Sri Gutama, Edisi Pertama (Yogyakarta: Unit Penerbitan Sanggar Candi Sapta Rengga, 2010), hlm. 7.

7 Ibid., hlm. 7-8.
} 
pribadi yang menerimanya sedangkan ajaran yang berasal dari wahyu itu tidak terbatas untuk Bapak Hardjosopoero saja melainkan untuk disampaikan kepada yang lain ${ }^{8}$.

Bapa Panuntun Sri Gutama menyebarkan ajaran Sapta Darma melalui beberapa cara menurut situasi, kondisi setempat dengan cara selaras dan serasi sesuai budaya pribadi bangsa Indonesia dengan semboyan "Rawe-rawe rantas malang-malang putung"9. Panuntun Agung Sri Gutama dengan rombongan melakukan peruwatan dan penyebaran ajaran Agama Sapta Darma ke Seluruh Indonesia dari tahun 1956-1960. Terdapat 102 perjalanan peruwatan dan penyebaran Sapta Darma di berbagai daerah. Berikut daerah-daerah yang disinggahi (Kutoarjo, Yogyakarta, Blitar, Kediri, Malang, Magetan, Randublatung, Surabaya, Sidoarjo, Gresik, Lumajang, Denpasar, Banyuwangi, Probolinggo, Jember, Kertosono/Nganjuk, Cirebon, Jakarta, Cilacap, Madiun, Tulungagung, Trenggalek, Klaten, Kroya, Wonosobo, Cepu, Purwokerto, Sleman, Bantul, Semarang, Ciamis, Purworejo, Makasar, Kebumen, Bojonegoro, Blitar, Ungaran, Serang, Rangkasbitung, Banjarnegara, Sumedang, Bogor, Kuningan, Semarang, Magelang, Banyumas, Mataram (Lombok), Ende (Flores), Lamongan, Pati, Blora, Kudus, Mojokerto, Karanganyar, Karangasem (Bali), Klungkung, Tuban, Demak) ${ }^{10}$.

Ajaran Kerokhanian Sapta Darma yaitu berdasarkan wahyu yang diturunkan kepada Bapa Hardjosopoero yaitu Wahyu Sujud, Wahyu Simbol Pribadi Manusia, Wewarah Tujuh, dan Wahyu Sesanti. Wahyu Sujud adalah memuat ajaran tentang tata cara ritual, manusia sujud kepada Allah Hyang Maha Kuasa. Wajib dilakukan oleh penghayat minimal satu kali dalam sehari semalam. Kegiatan sujud yang dilakukan di Sanggar (tempat sujud bersama/umum), dapat dilakukan bersama-sama dengan Tuntunan Sanggar sewaktu-waktu. Wahyu Racut adalah memuat ajaran tentang tata cara rohani manusia untuk mengetahui alam langgeng atau melatih sowan atau tata cara menghadap Allah Hyang Maha Kuasa.

Wahyu Simbol Pribadi Manusia menjelaskan tentang asal mula, sifat watak dan tabiat manusia itu sendiri, serta bagaimana manusia harus mengendalikan nafsu agar dapat mencapai keluhuran budi sesuai dengan petunjuk dalam tulisan "Nafsu, Budi, Pakarti” yang tertera pada dasar hijau maya.

\footnotetext{
8 Wawancara dengan Bambang Purnomo, Ketua PERSADA DIY Yogyakarta, di Jl. Prof. Yohanes 1012, 1 April 2015.

${ }^{9}$ Ibid., hlm. 28.

${ }^{10}$ Sekertariat Tuntunan Agung Kerokhanian Sapta Darma, Sejarah Penerimaan Wahyu, hlm. 29-31
} 
Wewarah Tujuh, merupakan kewajiban hidup manusia di dunia sekaligus merupakan pandangan hidup dan pedoman hidup manusia. Dalam Wewarah Tujuh tersebut tersirat kewajiban hidup manusia dalam hubungannya dengan Allah Hyang Maha Kuasa, Pemerintah dan Negara, nusa dan bangsa, sesama umat makluk sosial, pribadinya sebagai makluk individu, masyarakat sekitar dan lingkungan hidupnya.

Wahyu Sesanti yang cukup jelas dan gampang dimengerti oleh siapapun, membuktikan suatu etika/ciri khas Sapta Darma yang menitik beratkan kepada warganya harus membahagiakan orang lain (tansah agawe pepadang lan maraning lian).

Warga Sapta Darma meyakini dan menjalankan kehidupannya dengan berpedoman pada wahyu Wewarah Pitu atau tujuh kewajiban suci. Dalam Wewarah Pitu diajarkan kepada warga Sapta Darma untuk menjalin hubungan baik dengan sesama warga dan umat beragama lainnya serta diajarkan berbuat baik kepada ciptaan-ciptaan Tuhan yang lain. Dalam Wewarah Pitu juga berisi ajaran-ajaran yang menjadi dasar warga Sapta Darma untuk menjalin hubungan dengan Tuhannya dan menjalankan kehidupan sebagai warga yang berbangsa dan bernegara. Sehingga bagi warga Sapta Darma ajaran Sapta Darma sudah lengkap sebagai pedoman hidup bagi warganya ${ }^{11}$.

Ketujuh kewajiban suci tersebut antara lain : 1). Setia tuhu kepada Allah Hyang Maha Agung, Maha Rokhim, Maha Adil, Maha Wasesa, Maha Langgeng. 2). Dengan jujur dan suci hati, harus setia menjalankan Perundang-Undangan Negaranya. 3). Turut serta menyingsingkan lengan baju, menegakkan berdirinya Nusa dan bangsanya. 4). Menolong kepada siapa saja bila perlu, tanpa mengharapkan sesuatu balasan, melainkan berdasarkan rasa cinta dan kasih. 5). Berani hidup berdasarkan kepercayaan atas kekuatan diri sendiri. 6). Sikapnya dalam hidup bermasyarakat, kekeluargaan, harus susila beserta halusnya budi pakerti, selalu merupakan penunjuk jalan yang mengandung jasa serta memuaskan.7). Yakin bahwa keadaan dunia itu tiada abadi, melainkan selalu berubahubah (Anyakra manggilingan).

\section{Ajaran Kerokhanian Sapta Darma tentang Hubungan Warga Sapta Darma dengan Negara}

Pedoman yang mengatur hubungan warga Sapta Darma dengan Negara yaitu tercantum dalam Wewarah Tujuh pada nomor 2 dan 3. Penjelasan Sri Pawenang dalam Wewarah Tujuh nomor dua yaitu bahwa Undang-Undang negara merupakan

\footnotetext{
${ }^{11}$ Wawancara dengan Purboyo, Staf Tuntunan Agung Sapta Darma, Sanggar Candi Sapta Rengga, 2 April 2015.
} 
pengaturan/penertiban warganya demi tercapainya keselamatan, kesejahteraan serta kebahagiannya sehingga warga negara harus menjunjung tinggi menjalankannya dengan jujur dan suci hati serta penuh keikhlasan akan Undang-Undang negaranya. Sehingga warga Sapta Darma yang tinggal di Indonesia harus melaksanakan dan menegakan serta mengamalkan Pancasila karena merupakan dasar falsafah Negara Republik Indonesia serta harus melaksanakan dan taat kepada Perundangg-Undangan Negara Indonesia yang berlaku sekarang atau hukum positif ${ }^{12}$.

Dalam Wewarah Tujuh nomor 3 Sri Pawenang memberi penjelasan bahwa warga Sapta Darma tidak boleh absen, masa bodoh atau ingkar dari tanggung jawab dalam membina dan mewujudkan keadilan, kemakmuran, kesejahteraan, kebahagiaan dan kejayaan bangsanya, melainkan harus ikut serta menyisingkan lengan baju bersama-sama atau bahu membahu berjuang dengan sepenuh kemampuannya, keahlian serta bidangnya masing-masing baik dalam bentuk tenaga dan pikiran. ${ }^{13}$

Senada dengan Sri Pawenang, Tuntunan Agung, Bapak Saekoen memberi penjelasan tentang Wewarah Tujuh nomor 3 yaitu melu cawe-cawe acancut tali wanda njaga adeing Nusa lan Bangsane artinya bahwa warga Sapta Darma harus ikut serta menyingsingkan lengan bajunya untuk menjaga berdiri tegaknya negara, artinya tidak boleh masa bodoh dalam menjaga keamanan negara. Para Tuntunan juga dapat mengaplikasikan Wewarah Tujuh nomor 3 dengan cara mengarahkan para warga Sapta Darma untuk berperilaku sesuai dengan Wewarah Tujuh ${ }^{14}$. Menjadi warga Sapta Darma tidak boleh melanggar Peraturan dan Perundang-undangan Pemerintah, karena jika melanggar Peraturan dan Perundang-undangan Pemerintah berarti sudah menyalahi ajaran Sapta Darma. ${ }^{15}$

\section{Permasalahan hak-hak Sipil Penghayat Kerokhanian Sapta Darma}

Penelitian ini memfokuskan pada enam hak-hak sipil yang masih bermasalah dalam pemenuhannya kepada kelompok penghayat Kerokhanian Sapta Darma. Keenam hak-hak tersebut antara lain yaitu:

a. Hak atas pencantuman identitas di kolom agama dalam KTP

\footnotetext{
${ }^{12}$ Sri Pawenang, Wewarah Kerokhanian Sapta Darma Jilid-I (Yogyakarta: Sekretariat Tuntunan Agung Unit Penerbitan), hlm 26-27

13 Ibid., hlm. 27-28.

${ }^{14}$ Wawancara dengan Saekoen, Tuntunan Agung Sapta Darma, Sanggar Candi Sapta Rengga, 31 Mei 2015.

15 Wawancara dengan Purboyo, Staf Tuntunan Agung Sapta Darma, Sanggar Candi Sapta Rengga, 2 April 2015.
} 
Pencantuman identitas agama dalam kolom agama di KTP bagi penghayat Kerokhanian Sapta Darma sebelum dikeluarkannya UU Administrasi dan Kependudukan No 23 Tahun 2006 yaitu ada yang mengisikan identitas agama di KTP dengan salah satu agama yang diakui negara. Penulis juga menemukan adanya warga Sapta Darma yang dapat mencantumkan Sapta Darma sebagai identitas agamanya di KTP. Seperti yang terjadi pada Pak Bambang dan Pak Subroto. Bahkan salah satu staf Tuntunan dalam kolom agama di KTPnya saat ini masih tertuliskan sebagai Sapta Darma.

Penghayat Kerokhanian Sapta Darma yang mencantumkan identitas agama di KTP dengan salah satu agama yang diakui negara dikarenakan adanya dua faktor, yaitu: pertama, faktor internal, dicantumkannya agama yang diakui negara dikarenakan untuk memudahkan penghayat kepercayaan dalam mengakses layanan publik dan mendapatkan hak-hak sipilnya. Kedua, merupakan faktor ekternal, dicantumkannya agama resmi dalam kolom agama di KTP bukanlah dari keinginan penghayat kepercayaan melainkan petugas yang melayani mencantumkannya demikian tanpa mengkonfirmasi kepada penghayat terlebih dahulu. Sedangkan penghayat Kerokhanian Sapta Darma yang dapat mencantumkan Sapta Darma sebagai identitas agama di KTPnya dikarenakan mempunyai kedekatan dengan pejabat dan petugas setempat yang melayani pembuatan KTP.

Setelah dikeluarkannya UU NO 23 Tahun 2006, penghayat Kerokhanian Sapta Darma sudah banyak yang mengosongkan identitas agama pada kolom agama KTP. Hampir seluruh Tuntunan dan sebagian besar pengurus Kerokhanian Sapta Darma sudah mengosongkan identitas agama pada kolom agama KTP.

b. Hak atas pencatatan dan registrasi perkawinan antar penghayat

Sebelum dikeluarkannya UU No 23 Tahun 2006, pencatatan dan registrasi perkawinan antar penghayat Kerokhanian Sapta Darma berdasarkan UndangUndang Nomor 1 tahun 1974 yang berbunyi "Perkawinan adalah sah, apabila dilakukan menurut hukum masing-masing agamanya dan kepercayaannya itu”.

Penghayat Kerokhanian Sapta Darma ada yang melaksanakan pernikahan secara Sapta Darma dan ada yang melaksanakan pernikahan dengan cara salah satu agama. Mereka yang melakukan pernikahan secara Sapta Darma adalah warga Sapta 
Darma yang tidak mengalami kesulitan dalam pencatatan pernikahannya di catatan sipil pada masanya dan daerahnya karena kebijakan daerah satu dengan yang lain berbeda. Salah satu warga Sapta Darma pada tahun 1985 tidak bisa melangsungkan pernikahan secara Sapta Darma di Pati akan tetapi, ia bisa menikah secara Sapta Darma di daerah lain, Purwokerto. Hal itu bisa terjadi dikarenakan tergantung dari petugas Catatan Sipil.

Menurut Pak Bambang, bahwa Sapta Darma mulai tidak bisa menikahkan warganya secara Sapta Darma mulai tahun 1985, hal itu dikarenakan pada waktu itu ada orang yang salah persepsi bahwa Sapta Darma dapat mengeluarkan akta nikah sendiri, hal itu sampai terdengar oleh pihak Kejaksaan sehingga pernikahan secara Sapta Darma dilarang. Padahal pihak Sapta Darma tidak dapat mengeluarkan akta nikah sendiri, melainkan setelah menikah secara Sapta Darma kemudian dicatatkan di catatan sipil. Hal itu seperti yang dilakukan oleh Pak Bambang yang menikah secara Sapta Darma di Yogyakarta tahun $1976^{16}$.

Setelah dikeluarkannya PP No. 37 tahun 2007 tentang Pelaksanaan UndangUndang No. 23 Tahun 2006, ikut mempercepat efektifitas pemenuhan hak sipil perkawinan warga penghayat kepercayaan. Dalam PP Nomor 37, Bab I Pasal I ayat 20 dikatakan bahwa Surat Perkawinan Penghayat Kepercayaan adalah bukti perkawinan Penghayat Kepercayaan yang dibuat, ditandatangani dan disahkan oleh Pemuka Penghayat Kepercayaan. Terlebih Bab X Pasal 81 PP Nomor 37 Tahun 2007 juga menegaskan bahwa, "Perkawinan penghayat kepercayaan dilakukan di hadapan pemuka penghayat kepercayaan. Pemuka penghayat kepercayaan ditunjuk dan ditetapkan oleh organisasi penghayat kepercayaan untuk mengisi dan menandatangani surat perkawinan penghayat kepercayaan".

Setelah dikeluarkannya Undang-Undang No. 23 Tahun 2006 dan PP No. 37 tahun 2007 warga Sapta Darma sudah tidak ada kesulitan untuk mencatatkan pernikahanya di catatan sipil meski pernikahannya dilakukan secara Sapta Darma. Hal ini dipertegas dengan pernyataan Pimpinan Persatuan Warga Sapta Darma Pusat, Bapak Naen Soeryono "dulu masalah perkawinan itu terhambat sekarang tidak"

c. Hak atas Pendidikan Anak-Anak Penghayat Sesuai dengan Keyakinannya

\footnotetext{
${ }^{16}$ Wawancara dengan Bambang Purnomo, Ketua PERSADA DIY Yogyakarta, di Jl. Prof. Yohanes 1012, 1 April 2015.

17 Wawancara dengan Naen Soeryono, Ketua PERSADA Pusat, di Sanggar Candi Sapta Rengga, tanggal 8 Mei 2015.
} 
Peraturan Pemerintah Republik Indonesia Nomor 55 Tahun 2007 tentang Pendidikan Agama Dan Pendidikan Keagamaan. Dalam Bab III Pendidikan Keagamaan, Pasal 9 disebutkan sebagai berikut: “(1) Pendidikan keagamaan meliputi pendidikan keagamaan Islam, Kristen, Katolik, Hindu, Buddha, dan Khonghucu”. Peraturan tersebut belum dapat mengakomodasi pendidikan agama bagi anak-anak penghayat Kepercayaan karena Undang-undang tersebut hanya mengatur hak pendidikan bagi pemeluk-pemeluk agama.

Anak-anak penghayat kepercayaan mau tidak mau harus mengikuti mata pelajaran agama yang tidak menjadi keyakinannya. "Terus pendidikan itu juga masih belum, pendidikan bagi anak SD, SMP, SMA yang anak penghayat kepercayaan masih bermasalah karena harus mengikuti salah satu agama"18. Dalam hal ini juga yang dialami penghayat Kerokhanian Sapta Darma, para anak penghayat Kerokhanian Sapta Darma memilih salah satu agama meskipun tidak menjadi keyakinannya, disebabkan untuk memudahkan mereka mengikuti pelajaran agama, karena dengan tidak mengikuti salah satu mata pelajaran agama artinya tidak akan mendapatkan nilai dalam mata pelajaran agama dan hal tersebut dapat mengurangi jumlah rata-rata nilai Rapor.

d. Hak atas sumpah jabatan dengan tata cara penghayat

Hak atas sumpah jabatan dengan tata cara penghayat belum mendapatkan perlindungan dan payung hukum yang jelas. Karena dalam Undang-Undang Republik Indonesia No. 22 Tahun 1999 Tentang Pemerintahan Daerah, secara nyata dalam penjelasan pasal 42, Undang-Undang ini mengatakan bahwa sumpah yang dilakukan oleh pejabat Negara haruslah menurut agama yang diakui oleh pemerintah $^{19}$.

Pada tahun 1986 salah satu warga Sapta Darma bisa melakukan sumpah jabatan Pegawai Negeri Sipil di Dinas Pendidikan secara Sapta Darma. Dan pada tahun 1997 salah satu warga yang menjadi Pegawai BUMN dapat melakukan Sumpah Jabatan dengan cara Sapta Darma. Dan pada tahun 2000an ada warga Sapta Darma yang menjadi Pegawai Negeri Sipil di Departemen Keuangan dan dapat melakukan sumpah jabatan secara Sapta Darma. Sekitar tahun 2015 sumpah jabatan secara Sapta

18 Ibid.,

19 Tedi Kholiludin, Kuasa Negara Atas Agama Politik Pengakuan, Diskursus " Agama Resmi” dan Diskrimina Hak Sipil (Semarang: RaSAIL Media Group, 2009), hlm. 223. 
Darma belum dapat dilaksanakan hal itu terjadi pada Bapak Susilo di Propinsi Semarang tidak dapat dilantik sebagai Pegawai Negeri di Dinas Perikanan dan Kelautan dikarenakan kolom agama di KTPnya kosong.

e. Hak atas lahan pemakaman dan penguburan sesuai dengan kepercayaannya

Sebelum ada Perber Dua Menteri No. 43 dan No. 41 Tahun 2009, warga Sapta Darma yang meninggal dunia untuk daerah Jawa Timur dan Jawa Tengah tidak dimakamkan melainkan diperabukan. Kemudian setelah dikeluarkannya Perber Dua Menteri No. 43 dan No. 41 Tahun 2009, banyak warga yang mempunyai tanah makam sendiri. Daerah Jawa Barat, sampai saat ini warga Sapta Darma masih mengalami kesulitan untuk memakamkan warganya sesuia ajaran Sapta Darma.

Beberapa bulan kemarin muncul di berbagai media masa bahwa salah satu warga Sapta Darma di Brebes tidak dapat di makamkan di Tempat Pemakaman Umum. Akan tetapi masalah tersebut sudah terselesaikan dan warga Sapta Darma tersebut dapat dimakamkan di Tempat Pemakaman Umum setelah Pengurus PERSADA menghadap kepada Gubernur Jawa Tengah. Kemudian Gubernur Jawa Tengah, Bapak Ganjar Pranowo menginstruksikan kepada seluruh Bupati Jawa Tengah untuk menyediakan pemakaman bagi penghayat kepercayaan. ${ }^{20}$

Tidak diperbolehkannya Ibu Saudah, warga Sapta Darma di Brebes di makamkan di Tempat Pemakaman Umum menurut Bapak Naen Soeryono dikarenakan ada dua faktor yang menyebabkan yaitu: Pertama, ada kelompok masyarakat di tempat Ibu Saudah tinggal tidak menghendaki Sapta Darma berkembang di daerahnya sehingga mencari cara supaya warga Sapta Darma tidak berkembang dan tidak melakukan syiar di daerahnya. Menurut Bapak Naen Soeryono bahwa hal tersebut terjadi pada daerah Brebes sampai Indramayu. Kedua, faktor internal dari warga Sapta Darma, dikarenakan terlalu ekslusif dan fanatik dan tidak mau bergaul dengan masyarakat sekitar.

f. Hak untuk berkumpul dan membangun rumah ibadah

Saat ini warga Sapta Darma mengalami kendala pendirian Sanggar terutama di daerah Jawa Barat karena ada sekelompok masyarakat yang belum bisa menerima warga Sapta Darma di daerahnya dengan alasan Sanggar identik dengan rumah ibadah agama-agama besar. Kendala Pendirian Sanggar juga terjadi di daerah

\footnotetext{
${ }^{20}$ Wawancara dengan Naen Soeryono, Ketua PERSADA Pusat, di Sanggar Candi Sapta Rengga, tanggal 8 Mei 2015.
} 
Lampung, yang sampai saat ini pihak Sapta Darma belum menemukan penyebabnya dan sedang dilakukan penetian atas hal tersebut.

Dalam Sapta Darma juga masih banyak Sanggar yang gabung dengan rumahrumah warga Sapta Darma dikarenakan untuk membangun Sanggar dibutuhkan tidak sedikit dana, dalam hal ini pihak PERSADA memaklumi dan memperbolehkan adanya Sanggar yang masih bergabung dengan rumah warga. Sanggar di Surabaya sudah mencapai 30an Sanggar, begitu juga di Bali, kurang lebih ada sekitar 30 Sanggar.

Dari pemaparan diatas, dapat dilihat adanya ketidakefektifan dari Peraturanperaturan dan Undang-undang yang ada. UU NO. 23/2006 mengenai pembuatan KTP, pasal 61 ayat 2 yang mengatur penghayat Kepercayaan terhadap Tuhan Yang Maha Esa untuk tidak mengisi dalam kolom agama di KTP dapat dijalankan secara efektif apabila peraturan tersebut disosialisasikan dengan baik kepada seluruh pihak terutama petugaspetugas yang melayani pembuatan KTP, sehingga tidak ada lagi petugas-petugas yang melayani pembuatan KTP mencantumkan agama pada KTP penghayat Kepercayaan terhatap Tuhan Yang Maha Esa pada umumnya dan secara khusus kepada penghayat Kerokhanian Sapta Darma. Selanjutnya perlunya negara menjamin penuh atas dikeluarkannya Peraturan dan Perundang-undangan yang mengatur hak-hak sipil penghayat Kepercayaan. Dengan demikian tidak ada lagi penghayat yang khawatir untuk mematuhi peraturan tersebut.

Untuk hak-hak sipil penghayat Kerokhanian Sapta Darma yang belum mendapat payung hukum yang jelas seperti hak untuk mendapatkan pendidikan agama dan sumpah jabatan sesuai keyakinannya, seharusnya dapat mengacu pada pasal 28E ayat (1) ditegaskan bahwa setiap orang bebas memeluk agama dan beribadat menurut agamanya, memilih pendidikan dan pengajaran, memilih pekerjaan, memilih kewarganegaraan, memilih tempat tinggal di wilayah negara, meninggalkan dan berhak kembali. Sementara itu di ayat (2) ditegaskan bahwa setiap orang berhak atas kebebasan meyakini kepercayaan, menyatakan pikiran dan sikap sesuai dengan hati nuraninya. Pasal 29 Ayat (1) ditegaskan bahwa negara berdasarkan atas ketuhanan Yang Maha Esa, sedangkan ayat (2) ditegaskan negara menjamin kemerdekaan tiap-tiap penduduk untuk memeluk agamanya masing-masing dan beribadat menurut agama dan kepercayaannya itu. Akan tetapi, dalam realitanya penghayat Kepercayaan masih belum mendapat jaminan dari 
Undang-undang tersebut sehingga penghayat Kerokhanian Sapta Darma masih mengalami kendala dalam memenuhi kedua hak sipil tersebut.

Melihat Indonesia merupakan negara yang memiliki masyarakat multikultur, seharusnya langkah-langkah yang diambil Pemerintah dalam mengambil kebijakan memperhatikan aspek-aspek multikultur, sehingga tidak ada masyarakat yang didiskriminasikan. Dalam hal ini Bhikhu Parekh mengajukan kesetaraan dalam masyarakat multikultur. Menurut Bhikhu Parekh kesetaraan yaitu melibatkan kebebasan atau kesempatan untuk menjadi berbeda, dan memperlakukan manusia secara setara untuk menuntut kita mempertimbangkan kesamaan beserta keberbedaan. Ketika perbedaan tidak relevan, kesetaraan akan menghasilkan perlakuan yang seragam atau identik; perbedaan-perbedaan tersebut membutuhkan perlakuan yang berbeda. Hak-hak yang setara tidak berarti hak-hak yang identik, bagi individu dengan latar belakang budaya dan kebutuhan yang berbeda, mungkin memerlukan hak-hak yang berbeda untuk menikmati isi dari hak-hak tersebut. Kesetaraan atas penghormatan melibatkan tidak saja penolakan atas keberbedaan yang tidak relevan ${ }^{21}$.

Mengacu pada Will Kymlicka ${ }^{22}$ untuk menjadi negara multikultural, Indonesia perlu: 1). Menegaskan bahwa Indonesia milik semua warga negara, 2) Seharusnya sudah tidak ada lagi kebijakan-kebijakan Negara Indonesia yang mengasimilasi atau mengecualikan anggota minoritas atau kelompok-kelompok non-dominan. Sebaliknya, negara harus menerima bahwa individu dapat mengakses lembaga-lembaga negara, dan bertindak sebagai warga negara penuh dan setara dalam kehidupan politik, tanpa harus menyembunyikan atau menyangkal identitas etnokultural mereka. Oleh karena itu seharusnya tidak ada kebijakan yang mendiskriminasikan penghayat Kepercayaan terhadap Tuhan Yang Maha Esa. 3). Indonesia perlu mengakui sejarah ketidakadilan yang dilakukan kepada minoritas / kelompok non-dominan oleh kebijakan-kebijakan yang lebih yang memanifestasikan keinginan untuk mengarahkan penghayat Kepercayaan menjadi penganut agama yang diakui negara.

Sudah semestinya Pemerintah Indonesia memberi kesempatan terhadap penghayat Kerokhanian Sapta Darma untuk menjadi berbeda dengan penganut agama, sehingga

\footnotetext{
${ }^{21}$ Bhikhu Parekh, Rethinking Multiculturalism Keberagaman Budaya dan Teori Politik, terj. IMPULSE (Yogyakarta: Kanisius, 2012), hlm. 318-319.

${ }^{22}$ Will Kymlicka. "The Global Difussion of Multiculturalism: Trends, Causes, Consequences” dalam Stephen Tierney (ed.), Accomodating Cultural Diversity, (USA: Ashgate Publishing Company, 2007), hlm. 18-19.
} 
arahan dan usaha-usaha untuk menjadikan penghayat Kerokhanian Sapta Darma sebagai penganut salah satu agama yang diakui dapat diminimalisir. Pemberian kesempatan untuk berbeda terhadap penghayat Kerokhanian Sapta Darma perlu diimbangi dalam memperlakukan mereka secara setara dengan mempertimbangkan kesamaan beserta keberbedaan. Oleh karena itu diharapkan Pemerintah Indonesia sebelum mengeluarkan peraturan untuk penghayat Kepercayaan pada umumnya dan khususnya Kerokhanian Sapta Darma supaya mempelajari secara mendalam dari segala aspek terlebih dahulu tentang penghayat kepercayaan.

\section{SIMPULAN}

Berdasarkan tulisan di atas, dapat disimpulkan bahwa adanya permasalahan hakhak sipil penghayat kepercayaan terhadap Tuhan Yang Maha Esa, yakni Sapta Darma disebabkan adanya perbedaan kebijakan Negara yang mengatur penganut agama dan penghayat kepercayaan. Dari penelitian ini penulis menemukan bahwa terdapat beberapa permasalahan hak-hak sipil penghayat Kerokhanian Sapta Darma, terutama sebelum adanya UU No. 23/2006.

Penulis juga menemukan bahwa ada ketidakefektifan dari Peraturan-peraturan dan Undang-undang yang mengatur penghayat keprcayaan. UU NO. 23/2006 mengenai pembuatan KTP, pasal 61 ayat 2 yang mengatur penghayat Kepercayaan terhadap Tuhan Yang Maha Esa untuk tidak mengisi dalam kolom agama di KTP. Mengosongkan kolom agama di KTP bagi penghayat kepercayaan bukan menjadi solusi, karena menimbulkan permasalahan hak-hak sipil lainnya. Oleh karena itu, perlu ada jaminan penuh dari Negara atas dikeluarkannya Peraturan dan Perundang-undangan yang mengatur hak-hak sipil penghayat Kepercayaan. Dengan demikian tidak ada lagi penghayat yang khawatir untuk mematuhi peraturan tersebut.

\section{DAFTAR PUSTAKA}

El Hafidy, H.M As'ad, Aliran-aliran Kepercayaan dan Kebatinan di Indonesia, Jakarta: Ghalia Indonesia, 1982.

Kholiludin, Tedi. Kuasa Negara Atas Agama Politik Pengakuan, Diskursus "Agama Resmi” dan Diskriminasi Hak Sipil, Semarang: RaSaIL Media Group, 2009.

Kymlicka, Will. "The Global Difussion of Multiculturalism: Trends, Causes, Consequences" dalam Stephen Tierney (ed.), Accomodating Cultural Diversity, USA: Ashgate Publishing Company, 2007. 
Musdah Mulia Siti "Potret Kebebasan Beragama dan Berkeyakinan di Era Reformasi" dalam Elza Peldi Taher, ed., Merayakan Kebebasan Beragama Bunga Rampai 70 Tahun Djohan Effendi, Jakarta: ICRP kerjasama dengan Penerbit Buku Kompas, 2009.

Parekh, Bhikhu. Rethinking Multiculturalism Keberagaman Budaya dan Teori Politik, terj. IMPULSE, Yogyakarta: Kanisius, 2012.

Rohmawati, Hanung Sito. "Agama sebagai Indeks Kewarganegaraan, Studi atas Penghayat Kerokhanian Sapta Darma di Sanggar Candi Sapta Rengga". Tesis tidak dipublikasikan, pada Paska Sarjana UIN Sunan Kalijaga Yogyakarta Program Studi Agama dan Fonsentrasi Agama dan Resolusi Konflik, 2015.

Sekertariat Tuntunan Agung Kerokhanian Sapta Darma, Sejarah Penerimaan Wahyu Wewarah Sapta Darma dan Perjalanan Panuntun Agung Sri Gutama, Edisi Pertama, Yogyakarta: Unit Penerbitan Sanggar Candi Sapta Rengga, 2010.

Seri Pembinaan Penghayat Kepercayaan Terhadap Tuhan YME Membangun Komunikasi Antar Umat Beragama dengan Penghayat Kepercayaan Terhadap Tuhan YME. JAKARTA: Departemen Pendidikan dan Kebudayaan Direktorat Jenderal Kebudayaan Direktorat Pembinaan Penghayat Kepercayaan Terhadap Tuhan YME Proyek Inventarisasi Kepercayaan Terhadap Tuhan YME 1985/1986.

Supardi DS Iman, "Konflik Antara Golongan Kerohanian Sapta Darma Dengan Golongan Santri Di Gresik 1978-1983”, Universitas Jember, Makalah diseminarkan pada seminar akademik mahasiswa Sejaeah Universitas Negeri seJawa, Yogyakarta 9-10 Nov 1985.

Trisno, S. Sutanto, Politik Kesetaraan, dalam Dalam Elza Peldi Taher (ed.), Merayakan Kebebasan Beragama: Bunga Rampai Menyambut 70 Tahun Djohan Effendi Jakarta: ICRP-Kompas, 2009. 